\title{
STUDI KOMPARATIF METODE INVESTIGASI KELOMPOK DAN METODE NUMBER HEAD TOGETHER (NHT) PADA MATA PELAJARAN IPS TERHADAP PENINGKATAN KOMPETENSI SOSIAL SISWA DI SMPN 3 CIPONGKOR
}

\author{
Rio Teguh \\ STKIP Subang \\ rioteguh1@gmail.com
}

\begin{abstract}
This study aims to study the improvement of social students' competencies in social studies learning by using the Group Investigation and Number Heads Together (NHT) methods which have been carried out at Cipongkor Middle School, West Bandung Regency. This research is motivated by students with low competence and teacher understanding will require alternative learning methods in the social studies learning process so that social studies often consider the lessons taken and saturate. In addition, based on observations made before the study, there were several issues discussed: the lack of active students in learning, social studies learning consisted only of memorization and evolution, and the lack of teachers who mastered learning methods. The results of this study are expected to be useful to enrich the knowledge of social studies teachers about social studies learning methods that can be used in improving social student competency as an indicator of improving the quality of student learning processes and outcomes, as well as a constructive resource for the school where this research improves students' social relations. using a quasi-experimental method with a nonequivalent post test group design. The population in this study were all students of class VIII even semester 2013-2014 academic year, while the sample was 35 students of class VIII B and 35 students of class VIII D. Based on the results of data analysis collected for the study, it can be used for this study. can further improve students' social competence compared to the application of the Number Heads Together (NHT) method.
\end{abstract}

Keywords: Group Investigation Method, Number Heads Together (NHT) Method and Student Social Competence

\section{ABSTRAK}

Penelitian ini bertujuan untuk mengetahui peningkatan kompetensi social siswa pada pembelajaran IPS dengan menggunakan metode Investigasi Kelompok dan Metode Number Heads Together (NHT) telah dilakukan di SMPN 3 Cipongkor, Kabupaten Bandung Barat. Penelitian ini dilatarbelakangi oleh rendahnya kompetensi social siswa dan pemahaman guru akan pentingnya metode pembelajaran alternative pada proses pembelajaran IPS sehingga sering kali IPS dianggap sebagai pelajaran yang membosankan dan menjenuhkan. Selain itu, berdasarkan observasi yang dilakukan sebelum penelitian, terdapat beberapa masalah diantaranya: kurang aktifnya siswa dalam belajar, pembelajaran IPS hanya berupa hafalan dan teoritis, serta kuranya guru menguasai metode 
pembelajaran. Hasil penelitian ini diharapkan bermanfaat untuk memperkaya pengetahuan guru IPS mengenai metode-metode pembelajaran IPS yang dapat digunakan dalam meningkatkan kompetensi social siswa sebagai indicator peningkatan kualitas proses dan hasil belajar siswa, serta sebagai masukan yang membangun bagi sekolah tempat penelitian ini berlangsung dalam rangka meningkatkan kompetensi social siswa. Penelitian ini menggunakan metode quasi eksperimen dengan desain nonequivalent group post test. Populasi dalam penelitian ini adalah seluruh siswa kelas VIII semester genap tahun pelajaran 2013-2014, sedangkan sampelnya adalah 35 orang siswa kelas VIII B dan 35 orang siswa kelas VIII D. berdasarkan hasil analisis data yang terkumpul selama penelitian, dapat disimpulkan bahwa penerapan Metode Investiigasi Kelompok lebih dapat meningkatkan kompetensi social siswa dibandingkan dengan penerapan metode Number Heads Together (NHT).

Kata kunci : Metode Investigasi Kelompok, Metode Number Heads Together (NHT) dan Kompetensi Sosial Siswa

\section{A. Pendahuluan}

Pendidikan pada hakikatnya adalah perubahan peribadi manusia yang meliputi perubahan pengetahuan, Sikap dan perilaku. Pendidikan juga merupakan bagian dari proses kebudayaan dalam arti bahwa melalui pendidikan manusia didewasakan. Melalui pendidika belajar pengetahuan, mendapat pendidikan nilai, dan sejumlah kompetensi sebagai bekal dalam menghadapi kehidupannya di masa yang akan dating.

Pembelajaran bukan sekedar menyampaikan sejumlah informasi dari guru kepada peserta didik, melainkan lebih luas lagi, yaitu bersifat mendidik. Untuk itu, proses pembelajaran harus berlangsung dalam suasana yang bersifat mendidik dan melalui interaksi yang bersifat dialogis. Tugas guru saat ini diharapkan dapat memotivasi siswa untuk mencari informasi baru di luar kelas, karena guru bukan satusatunya sumber belajar. Guru sebagai pengendali proses pembelajaran di kelas dapat melaksanakan proses pembelajarannya melalui strategi pembelajaran yang lebih terbuka dengan berbasis aktivitas peserta didik, menurut Wrightman, (1977) dalam Usman

mengemukakan bahwa "peranan guru adalah terciptanya serangkaian tingkah laku yang saling berkaitan yang dilakukan kepada peserta didik. Berbagai strategi pembelajaran dapat berupa kerja kelompok, survey 
Didaktik : Jurnal IImiah PGSD STKIP Subang, ISSN Cetak : 2477-5673 ISSN Online : 2614-722X Volume V Nomor 2, Desember 2019

lapangan, dan seminar praktek lapangan".

Salah satu strategi yang dapat dilakukan pada mata pelajaran IPS yaitu penggunaan model pembelajaran kooperatif (Cooperative Learning). Banyaknya metode pembelajaran dalam model kooperatif peneliti mengambil dua metode yang ada pada model kooperatif metode tersebut yaitu Metode Investigasi Kelompok sebagai eksperimen pertama dan Metode Number Heads Together (NHT) sebagai kelas eksperimen kedua dalam penelitian ini.

Model kooperatif merupakan model pembelajaran yang berpusat pada siswa (student centerd) artinya pembelajaran tidak lagi hanya guru sebagai pusat belajar lagi, melainkan siswa dapat mengeksplor semua potensi yang ada pada dirinya untuk meningkatkan prestasi belajar, motivasi belajar dan kompetensi social siswa. Dimana dalam model pembelajaran kooperatif siswa dikelompokan antara $3-5$ orang siswa untuk setiap kelompok.

Untuk mencapai tujuan tersebut peniliti tertarik untuk melakukan penelitian yang berjudul "studi komparatif Metode Investigasi
Kelompok dan Metode Number Heads Together (NHT) pada Mata Pelajaran IPS terhadap peningkatan Kompetensi Sosial Siswa”.

Pembelajaran Kooperatif menurut Majid, A9 2013:174) adalah model pembelajaran yang mengutamakan kerja sama untuk mencapai tujuan pembelajaran. Pembelajaran kooperatif (cooperative learning) merupakan bentuk pembelajaran dengan siswa belajar dan bekerja dalam kelompokkelompok kecil secara kolaboratif, yang anggtanya terdiri dari 4 sampai 6 orang, dengan struktur kelompok yang bersifat heterogen.

Menurut Majid, A (2013:193) menyatakan bahwa metode adalah cara yang digunakan untuk mengimplementasikan rencana yang sudah disusun dalam kegiatannya agar tujuan yang telah tersusun tercapai secara optimal.

Metode

pembelajaran Investigasi Kelompok menurut Wahab (2007:60) adalah metode pembelajaran yang menenkankan pada aktivitas siswa untuk melakukan penyelidikan terhadap peristiwa, masalah atau topik tertentu melalui pengumpulan fakta-fakta atau informasi-informasi guna memperoleh 
Didaktik : Jurnal IImiah PGSD STKIP Subang, ISSN Cetak : 2477-5673 ISSN Online : 2614-722X Volume V Nomor 2, Desember 2019

pemahaman yang lebih jelas tentang suatu persoalan sehingga siswa berperan aktif menginvestigasi, bekerjasama dalam kelompok dan guru berperan sebagai fasilitator dan motivator selama pembelajaran berlangsung.

Model pembelajaran Kooperatif tipe Number Heads Together menurut Kagan dalam Nisa (2010:28), pembelajaran kooperatif merupakan strategi pembelajaran yang mengutamakan adanya kerjasama antar siswa dalam kelompok untuk mencapai tujuan pembelajaran.

Pembelajaran kooperatif tipe Number Heads Together merupakan salah satu tipe pembelajaran kooperatif yang menekankan pada struktur khusus yang dirancang untuk memengaruhi pola interkasi siswa dan memiliki tujuan untuk meningkatkan penguasaan akademik.

Menurut Mulyasa (2009:173) mengemukakan bahwa :Kompetensi Sosial adalah kemampuan individu dalam berinteraksi secara efektif dengan lingkungan hasil belajar dari perilaku-perilaku teratur dalam konteks social tertentu yang disesuaikan dengan budaya, lingkungan, situasi yang dihadapi serta nilai yang dianut oleh individu.

Menurut Trianto

(2007:78) menyatakan mengenai "investigasi Kelompok adalah metode pembelajaran yang melibatkan siswa sejak perencanaan, baik dalam menentukan topik maupun cara untuk mempelajarinya melalui investigasi.

\section{B. Metode Penelitian}

Metode penelitian yang dilakukan yaitu quasi eksperimen dengan membandingkan dua metode pembelajaran kelas VIII B sebagai kelas eksperimen pertama menggunakan Metode Investigasi Kelompok dan kelas VIII D sebagai kelas eksperimen kedua menggunakan Metode Number Heads Together (NHT). Jumlah pertemuan dalam penelitian ini sebanyak 3 kali pertemuan dengan kelas sampel dengan jumlah masingmasing kelas eksperimen berjumlah 35 siswa.

Instrumen sangat penting di dalam suatu penelitian, karena dengan instrument data yang diperlukan dapat diperoleh. Instrument yang digunakan dalam penelitian ini adalah format observasi dan tes. Adapun tes yang digunakan 
Didaktik : Jurnal IImiah PGSD STKIP Subang, ISSN Cetak : 2477-5673 ISSN Online : 2614-722X Volume V Nomor 2, Desember 2019

dalam penelitian ini adalah tes buatan guru yang berbentuk soal uraian. Selain instrument tes, dibuat pula format observasi yang dimaksudkan untuk melihat kompetensi social siswa dari setiap pertemuan dan untuk melihat keefektifan penggunaan metoode pembelajaran kooperatif pada proses pembelajaran di kelas yang disesuaikan dengan langkah penggunaannya. Format observasi dibuat dengan menyesuaikan pada indicator dan subindikator yang akan diukur melalui range antara nilai 1 sebagai nilai terendah sampai 4 sebagai nilai tertinggi.

Terdapat lima langkah teknik analisis data diantaranya: penskoran, (2) uji normalitas, (3) uji homogenitas dengan ANOVA, (4) uji hipotesis dengan ANOVA dan (5) analisis hasil observasi.

\section{Hasil Penelitian dan}

\section{Pembahasan}

\section{Kelas Eksperimen Pertama}

Data observasi didapatkan melalui kegiatan pengamatan di kelas berdasarkan pedomann observasi yang telah ditentukan sedangkan data tes dihasilkan dari soal post tes yang dibuat dalam bentuk tes terbuka (uraian) sebanyak 10 butir soal. Sebelum masuk kepada tahap pelaksanaan metode Investigasi Kelompok terdapat langkah-langkah sebagai berikut:

\section{a. Seleksi Topik}

Siswa dibagi ke dalam beberapa kelompok sesuai dengan kemampuan akademik dan jenis kelamin yang mewakili masingmasing strata tinggi, sedang dan rendah. Setelah penentuan tugas terbentuk langkah selanjutnya adalah merencanakan kerjasama kelompok dan guru bertugas membantu dalam pengumpulan informasi dan memfasilitasi pengaturan diskusi kelompok.

b. Merencanakan Kerjasama Pada tahap langkah-langkah kerja kelompok dilakukan pada pertemuan kedua dengan rincian sebagai berikut:

1) Masing-masing kelompok menentukan tujuan yang akan dilakukan pada tahap pelaksanaan investigasi.

2) Masing-masing kelompok bersama anggota menentukan bagaimana mempelajari Investigasi Kelompok. 
3) Tahap berikutnya pembagian tugas untuk masing-masing anggota kelompok.

4) Masing-masing kelompok menentukan tujuan melakukan investigasi sesuai topik yang sudah dipilih pada tahap sebelumnya.

c. Melaksanakan Investigasi Kelompok

Masing-masing anggota berkontribusi untuk usaha-usaha yang dilakukan kelompoknya agar mendapatkan hasil yang maksimal. Pada akhir investigasi siswa saling bertukar pendapat, berdiskusi, mengklarifikasi dan mensintesis semua gagasan dari data yang sudah terkumpul dan menyiapkan laporan hasil investigasi tersebut.

\section{d. Menyiapkan laporan akhir}

Masing-masing anggota kelompok menentukan pesan-pesan esensial dari hasil investigasi. Kemudian anggota kelompok melakukan diskusi untuk merencanakan apa yang akan mereka laporkan dan bagaimana mereka akan membuat presentasi di depan kelas termasuk siapa yang akan mempresentasikan hasil laporan investigasi dari kelompoknya.

e. Presentasi laporan

Dalam mempresentasikan hasil laporan kelompok masing-masing wakil kelompok tampil di depan kelas untuk menyajikan hasil laporan dengan berbagai bentuk sehingga anggota yang tidak tampil dapat menyimak apa yang disampaikan wakil kelompok.

\section{f. Evaluasi}

Pada tahap akhir guru memberikan evaluasi dan kesimpulan dari presentasi masing-masing kelompok mengenai materi Pranata Sosial dan manfaat apa yang dapat didapat dari melakukan investigasi kelompok.

Tabel 1

Perlakuan pertama metode Investigasi Kelompok

\begin{tabular}{|c|c|c|c|c|c|c|c|c|c|c|c|c|}
\hline No & $\begin{array}{c}\text { Indicator } \\
\text { kompetens } \\
\text { i social }\end{array}$ & $\begin{array}{c}\text { Sub } \\
\text { indicator } \\
\text { kompetensi } \\
\text { Social }\end{array}$ & 4 & $\%$ & 3 & $\%$ & 2 & $\%$ & 1 & $\%$ & Jml & $\%$ \\
\hline 1 & Living and & Bergiliran & - & - & 8 & 22.87 & 22 & 62.85 & 5 & 14.28 & 35 & 10 \\
\hline
\end{tabular}


Didaktik : Jurnal IImiah PGSD STKIP Subang, ISSN Cetak : 2477-5673 ISSN Online : 2614-722X Volume V Nomor 2, Desember 2019

\begin{tabular}{|c|c|c|c|c|c|c|c|c|c|c|c|c|}
\hline \multirow[b]{2}{*}{ No } & \multirow{2}{*}{$\begin{array}{l}\text { Indicator } \\
\text { kompetens } \\
\text { i social }\end{array}$} & \multirow{2}{*}{$\begin{array}{c}\text { Sub } \\
\text { indicator } \\
\text { kompetensi } \\
\text { social }\end{array}$} & \multicolumn{8}{|c|}{ Nilai } & \multirow[b]{2}{*}{$\mathrm{Jml}$} & \multirow[b]{2}{*}{$\%$} \\
\hline & & & 4 & $\%$ & 3 & $\%$ & 2 & $\%$ & 1 & $\%$ & & \\
\hline & \multirow{3}{*}{$\begin{array}{l}\text { Working } \\
\text { Together }\end{array}$} & & & & & & & & & & & 0 \\
\hline & & $\begin{array}{c}\text { Menghormat } \\
\mathrm{i}\end{array}$ & - & - & 8 & 22.87 & 22 & 62.85 & 5 & 14.28 & 35 & $\begin{array}{c}10 \\
0\end{array}$ \\
\hline & & $\begin{array}{c}\text { Membantu/ } \\
\text { menolong }\end{array}$ & - & - & 8 & 22.87 & 18 & 51.48 & 9 & 25.71 & 35 & $\begin{array}{c}10 \\
0 \\
\end{array}$ \\
\hline \multirow[t]{2}{*}{2} & \multirow{2}{*}{$\begin{array}{l}\text { Learning } \\
\text { sel control } \\
\text { and self } \\
\text { direction }\end{array}$} & $\begin{array}{c}\text { Mengikuti } \\
\text { petunjuk/atu } \\
\text { ran }\end{array}$ & - & - & 7 & 20 & 19 & 54.28 & 9 & 25.71 & 35 & $\begin{array}{c}10 \\
0\end{array}$ \\
\hline & & $\begin{array}{l}\text { Mengontrol } \\
\text { emosi }\end{array}$ & - & - & 11 & 31.42 & 15 & 42.85 & 9 & 25.71 & 35 & $\begin{array}{c}10 \\
0\end{array}$ \\
\hline \multirow[t]{2}{*}{3} & \multirow{2}{*}{$\begin{array}{c}\text { Sharing } \\
\text { ideas and } \\
\text { Experience } \\
\mathrm{s}\end{array}$} & $\begin{array}{l}\text { Menyampaik } \\
\text { an pendapat }\end{array}$ & - & - & 7 & 20 & 23 & 65.71 & 5 & 14.28 & 35 & $\begin{array}{c}10 \\
0\end{array}$ \\
\hline & & $\begin{array}{l}\text { Menerima } \\
\text { pendapat }\end{array}$ & - & - & 7 & 20 & 23 & 65.71 & 5 & 14.28 & 35 & $\begin{array}{c}10 \\
0\end{array}$ \\
\hline
\end{tabular}

Tabel 2

Perlakuan kedua metode Investigasi Kelompok

\begin{tabular}{|c|c|c|c|c|c|c|c|c|c|c|c|c|}
\hline \multirow{2}{*}{$\begin{array}{l}\mathrm{N} \\
\mathrm{O}\end{array}$} & \multirow{2}{*}{$\begin{array}{c}\text { Indicator } \\
\text { kompetens } \\
\text { i social }\end{array}$} & \multirow{2}{*}{$\begin{array}{c}\text { Sub } \\
\text { indicator } \\
\text { kompetensi } \\
\text { social }\end{array}$} & \multicolumn{8}{|c|}{ Nilai } & \multirow[t]{2}{*}{$\mathrm{Jml}$} & \multirow[t]{2}{*}{$\%$} \\
\hline & & & 4 & $\%$ & 3 & $\%$ & 2 & $\%$ & 1 & $\%$ & & \\
\hline \multirow[t]{3}{*}{1} & \multirow{3}{*}{$\begin{array}{l}\text { Living and } \\
\text { Working } \\
\text { Together }\end{array}$} & Bergiliran & - & - & 23 & 65.71 & 12 & 34.28 & - & - & 35 & 100 \\
\hline & & $\begin{array}{c}\text { Menghormat } \\
\text { i }\end{array}$ & - & - & 20 & 57.14 & 15 & 42.85 & - & - & 35 & 100 \\
\hline & & $\begin{array}{l}\text { Membantu/ } \\
\text { menolong }\end{array}$ & - & - & 22 & 62.85 & 13 & 37.14 & - & - & 35 & 100 \\
\hline \multirow[t]{2}{*}{2} & \multirow{2}{*}{$\begin{array}{l}\text { Learning } \\
\text { sel control } \\
\text { and self } \\
\text { direction }\end{array}$} & $\begin{array}{l}\text { Mengikuti } \\
\text { petunjuk/atu } \\
\text { ran }\end{array}$ & - & - & 25 & 71.43 & 10 & 28.57 & - & - & 35 & 100 \\
\hline & & $\begin{array}{l}\text { Mengontrol } \\
\text { emosi }\end{array}$ & 5 & $\begin{array}{l}14 . \\
28\end{array}$ & 10 & 28.57 & 20 & 57.14 & - & - & 35 & 100 \\
\hline \multirow[t]{2}{*}{3} & \multirow{2}{*}{$\begin{array}{c}\text { Sharing } \\
\text { ideas and } \\
\text { Experience } \\
\mathrm{s}\end{array}$} & $\begin{array}{l}\text { Menyampaik } \\
\text { an pendapat }\end{array}$ & 9 & $\begin{array}{l}25 . \\
71\end{array}$ & 14 & 40 & 12 & 34.28 & - & - & 35 & 100 \\
\hline & & $\begin{array}{l}\text { Menerima } \\
\text { pendapat }\end{array}$ & 5 & $\begin{array}{l}14 . \\
28\end{array}$ & 26 & 74.28 & 4 & 11.43 & - & - & 35 & 100 \\
\hline
\end{tabular}

Tabel 3

Perlakuan ketiga metode Investigasi Kelompok

\begin{tabular}{|c|c|c|c|c|c|c|c|c|c|c|c|c|}
\hline \multirow[t]{2}{*}{$N$} & \multirow{2}{*}{$\begin{array}{c}\text { Indicator } \\
\text { kompetens } \\
\text { i social }\end{array}$} & \multirow{2}{*}{$\begin{array}{c}\text { Sub } \\
\text { indicator } \\
\text { kompetensi } \\
\text { social }\end{array}$} & \multicolumn{8}{|c|}{ Nilai } & \multirow[t]{2}{*}{$\mathrm{Jml}$} & \multirow[t]{2}{*}{$\%$} \\
\hline & & & 4 & $\%$ & 3 & $\%$ & 2 & $\%$ & 1 & $\%$ & & \\
\hline \multirow[t]{3}{*}{1} & \multirow{3}{*}{$\begin{array}{c}\text { Living and } \\
\text { Working } \\
\text { Together }\end{array}$} & Bergiliran & $\begin{array}{l}1 \\
5\end{array}$ & $\begin{array}{l}42 . \\
85\end{array}$ & 10 & 28.57 & 10 & 28.57 & - & - & 35 & 100 \\
\hline & & $\underset{\mathrm{i}}{\text { Menghormat }}$ & $\begin{array}{l}1 \\
0 \\
\end{array}$ & $\begin{array}{l}28 . \\
57\end{array}$ & 10 & 28.57 & 15 & 42.85 & - & - & 35 & 100 \\
\hline & & Membantu/ & 1 & 28. & 15 & 42.85 & 10 & 28.57 & - & - & 35 & 100 \\
\hline
\end{tabular}


Didaktik : Jurnal IImiah PGSD STKIP Subang, ISSN Cetak : 2477-5673 ISSN Online : 2614-722X Volume V Nomor 2, Desember 2019

\begin{tabular}{|c|c|c|c|c|c|c|c|c|c|c|c|c|}
\hline \multirow{3}{*}{$\begin{array}{l}N \\
0\end{array}$} & \multirow{3}{*}{$\begin{array}{l}\text { Indicator } \\
\text { kompetens } \\
\text { i social }\end{array}$} & \multirow{2}{*}{$\begin{array}{c}\text { Sub } \\
\text { indicator } \\
\text { kompetensi } \\
\text { social }\end{array}$} & \multicolumn{8}{|c|}{ Nilai } & \multirow[t]{2}{*}{$\mathrm{Jml}$} & \multirow[t]{2}{*}{$\%$} \\
\hline & & & 4 & $\%$ & 3 & $\%$ & 2 & $\%$ & 1 & $\%$ & & \\
\hline & & menolong & 0 & 57 & & & & & & & & \\
\hline \multirow[t]{2}{*}{2} & \multirow{2}{*}{$\begin{array}{l}\text { Learning } \\
\text { sel control } \\
\text { and self } \\
\text { direction }\end{array}$} & $\begin{array}{l}\text { Mengikuti } \\
\text { petunjuk/atu } \\
\text { ran }\end{array}$ & $\begin{array}{l}2 \\
0\end{array}$ & $\begin{array}{l}57 . \\
14\end{array}$ & 15 & 42.85 & - & - & - & - & 35 & 100 \\
\hline & & $\begin{array}{c}\text { Mengontrol } \\
\text { emosi }\end{array}$ & $\begin{array}{l}3 \\
0\end{array}$ & $\begin{array}{l}85 . \\
71\end{array}$ & - & - & 5 & 14.28 & - & - & 35 & 100 \\
\hline \multirow[t]{2}{*}{3} & \multirow{2}{*}{$\begin{array}{c}\text { Sharing } \\
\text { ideas and } \\
\text { Experience } \\
\mathrm{s}\end{array}$} & $\begin{array}{l}\text { Menyampaik } \\
\text { an pendapat }\end{array}$ & 8 & $\begin{array}{l}22 . \\
85\end{array}$ & 12 & 34.28 & 5 & 14.28 & - & - & 35 & 100 \\
\hline & & $\begin{array}{l}\text { Menerima } \\
\text { pendapat }\end{array}$ & 5 & $\begin{array}{l}14 . \\
28\end{array}$ & 5 & 14.28 & 15 & 42.85 & - & - & 35 & 100 \\
\hline
\end{tabular}

\section{Kelas Eksperimen Kedua}

Langkah-langkah pembelajaran dengan menggunakan metode Number Heads Together (NHT) sebagai berikut:

\section{a. Penomoran}

Pada langkah pertama huru menjelaskan pembagian kelompok berdasarkan kemampuan akademik dan kemampuan kompetensi social yang berbeda. Anggota kelompok mewakili strata yang ada, dalam hal ini kemampuan akademik, kemampuan social dan jenis kelamin. Guru membagi siswa yang berjumlah 35 orang siswa menjadi 5 kelompok yang masing-masing kelompok terdiri dari 7 orang anggota.

b. Pengajuan pertanyaan

Tujuan dari pengajuan pertanyaan untuk mengetahui pemahaman dan penguasaan siswa terhadap tugas yang diberikan oleh guru. Selain itu, untuk mengarahkan perhatian siswa dan untuk mengubah prasangka yang keliru pada diri siswa.

\section{c. Berfikir bersama}

Semua siswa dalam satu kelompok berfikir bersama dan menyatakan pendapat terhadap jawaban pertanyaan itu serta meyakinkan tiap-tiap anggota mengetahui jawaban itu. Pada tahap ini siswa dalam kelompoknya mempunyai jawaban atau pendapat sendiri atas pertanyaan atau tugas yang diberikan. Jawaban atau pendapat itu kemudian didiskusikan, sehingga setiap siswa dalam kelompok tersebut memiliki jawaban yang sama. 
Siswa yang tergolong pintar atau kurang mengerti, saling bekerjasama sehingga tercipta proses pintar belajar yang efektif antar siswa.

\section{d. Pemberian jawaban}

Pada tahap akhir guru memanggil satu nomor tertentu dari salah satu kelompok secara acak, kemudian meminta siswa untuk tampil di depan kelas dan memberikan jawaban dari pertanyaan yang diberikan oleh guru. Kemudian guru memanggil nomor lain secara acak dari salah satu kelompok untuk memberikan tanggapan dari jawaban yang diberikan pertanyaan tadi. Jika jawaban siswa yang dipanggil pertama atau kurang tepat maka nomor yang dipanggil kedua dipersilahkan untuk memberikan tanggapannya. Jika jawaban yang disampaikan oleh siswa benar maka guru hanya memperkuat jawaban dari siswa yang memberikan tanggapan untuk seluruh kelas. Tetapi apabila jawaban siswa yang memberikan tanggapan salah atau kurang tepat maka guru memberikan arahan jawaban untuk memberikan jawaban yang benar.

Bagi siswa yang dipanggil menjawab pertanyaan dengan benar maka diberikan penghargaan berupa skor 4 (sangat baik) dan apabila jawaban kurang tepat maka skor 3 (baik) dan apabila jawaban siswa salah maka skor 2 (cukup) jika siswa tidak menjawab sama sekali ketika dipanggil guru maka skor 1 (kurang).

Tabel 4

Perlakuan pertama metode Number Heads Together

\begin{tabular}{|c|c|c|c|c|c|c|c|c|c|c|c|c|}
\hline \multirow[b]{2}{*}{$\begin{array}{l}N \\
\mathrm{O}\end{array}$} & \multirow{2}{*}{$\begin{array}{l}\text { Indicator } \\
\text { kompete } \\
\text { nsi social }\end{array}$} & \multirow{2}{*}{$\begin{array}{c}\text { Sub } \\
\text { indicator } \\
\text { kompetensi } \\
\text { social }\end{array}$} & \multicolumn{8}{|c|}{ Nilai } & \multirow[b]{2}{*}{$\mathrm{Jml}$} & \multirow[b]{2}{*}{$\%$} \\
\hline & & & 4 & $\%$ & 3 & $\%$ & 2 & $\%$ & 1 & $\%$ & & \\
\hline \multirow[t]{3}{*}{1} & \multirow{3}{*}{$\begin{array}{c}\text { Living } \\
\text { and } \\
\text { Working } \\
\text { Together }\end{array}$} & Bergiliran & - & - & - & - & 25 & 71.43 & 10 & 28.57 & 35 & 100 \\
\hline & & $\underset{i}{\text { Menghormat }}$ & - & - & 5 & 14.28 & 15 & 42.85 & 15 & 42.85 & 35 & 100 \\
\hline & & $\begin{array}{c}\text { Membantu/ } \\
\text { menolong }\end{array}$ & - & - & - & - & 22 & 62.85 & 13 & 37.14 & 35 & 100 \\
\hline 2 & $\begin{array}{c}\text { Learning } \\
\text { sel } \\
\text { control }\end{array}$ & $\begin{array}{c}\text { Mengikuti } \\
\text { petunjuk/atu } \\
\text { ran }\end{array}$ & - & - & - & - & 28 & 80 & 7 & 20 & 35 & 100 \\
\hline
\end{tabular}


Didaktik : Jurnal Ilmiah PGSD STKIP Subang, ISSN Cetak : 2477-5673 ISSN Online : 2614-722X Volume V Nomor 2, Desember 2019

\begin{tabular}{|c|c|c|c|c|c|c|c|c|c|c|c|c|}
\hline \multirow{3}{*}{$\begin{array}{l}N \\
0\end{array}$} & \multirow{3}{*}{$\begin{array}{l}\text { Indicator } \\
\text { kompete } \\
\text { nsi social } \\
\text { and self } \\
\text { direction }\end{array}$} & \multirow{2}{*}{$\begin{array}{c}\text { Sub } \\
\text { indicator } \\
\text { kompetensi } \\
\text { social }\end{array}$} & \multicolumn{8}{|c|}{ Nilai } & \multirow[b]{2}{*}{ Jml } & \multirow[b]{2}{*}{$\%$} \\
\hline & & & 4 & $\%$ & 3 & $\%$ & 2 & $\%$ & 1 & $\%$ & & \\
\hline & & $\begin{array}{c}\text { Mengontrol } \\
\text { emosi }\end{array}$ & - & - & - & - & 10 & 28.57 & 25 & 71.43 & 35 & 100 \\
\hline \multirow[t]{2}{*}{3} & \multirow{2}{*}{$\begin{array}{l}\text { Sharing } \\
\text { ideas and } \\
\text { Experien } \\
\text { ces }\end{array}$} & $\begin{array}{l}\text { Menyampaik } \\
\text { an pendapat }\end{array}$ & - & - & - & - & 10 & 28.57 & 25 & 71.43 & 35 & 100 \\
\hline & & $\begin{array}{l}\text { Menerima } \\
\text { pendapat }\end{array}$ & - & - & - & - & 22 & 62.85 & 13 & 37.14 & 35 & 100 \\
\hline
\end{tabular}

Tabel 5

Perlakuan kedua metode Number Heads Together

\begin{tabular}{|c|c|c|c|c|c|c|c|c|c|c|c|c|}
\hline \multirow{2}{*}{$\begin{array}{l}\mathrm{N} \\
\mathrm{O}\end{array}$} & \multirow{2}{*}{$\begin{array}{l}\text { Indicator } \\
\text { kompete } \\
\text { nsi social }\end{array}$} & \multirow{2}{*}{$\begin{array}{c}\text { Sub } \\
\text { indicator } \\
\text { kompetensi } \\
\text { social }\end{array}$} & \multicolumn{8}{|c|}{ Nilai } & \multirow[t]{2}{*}{$\mathrm{Jml}$} & \multirow[t]{2}{*}{$\%$} \\
\hline & & & 4 & $\%$ & 3 & $\%$ & 2 & $\%$ & 1 & $\%$ & & \\
\hline \multirow[t]{3}{*}{1} & \multirow{3}{*}{$\begin{array}{c}\text { Living } \\
\text { and } \\
\text { Working } \\
\text { Together }\end{array}$} & Bergiliran & - & - & 5 & 14.28 & 25 & 71.43 & 5 & 14.28 & 35 & 100 \\
\hline & & $\begin{array}{c}\text { Menghormat } \\
\mathrm{i}\end{array}$ & - & - & 5 & 14.28 & 25 & 71.43 & 5 & 14.28 & 35 & 100 \\
\hline & & $\begin{array}{l}\text { Membantu/ } \\
\text { menolong }\end{array}$ & - & - & - & - & 23 & 65.71 & 12 & 34.28 & 35 & 100 \\
\hline \multirow[t]{2}{*}{2} & \multirow{2}{*}{$\begin{array}{l}\text { Learning } \\
\text { sel } \\
\text { control } \\
\text { and self } \\
\text { direction }\end{array}$} & $\begin{array}{l}\text { Mengikuti } \\
\text { petunjuk/atu } \\
\text { ran }\end{array}$ & - & - & - & - & 30 & 85.71 & 5 & 14.28 & 35 & 100 \\
\hline & & $\begin{array}{l}\text { Mengontrol } \\
\text { emosi }\end{array}$ & - & - & - & - & 35 & 100 & - & - & 35 & 100 \\
\hline \multirow[t]{2}{*}{3} & \multirow{2}{*}{$\begin{array}{l}\text { Sharing } \\
\text { ideas and } \\
\text { Experien } \\
\text { ces }\end{array}$} & $\begin{array}{l}\text { Menyampaik } \\
\text { an pendapat }\end{array}$ & - & - & - & - & 12 & 34.28 & 23 & 65.71 & 35 & 100 \\
\hline & & $\begin{array}{l}\text { Menerima } \\
\text { pendapat }\end{array}$ & - & - & - & - & 35 & 100 & - & - & 35 & 100 \\
\hline
\end{tabular}

Tabel 6

Perlakuan ke tiga metode Number Heads Together

\begin{tabular}{|c|c|c|c|c|c|c|c|c|c|c|c|c|}
\hline \multirow{2}{*}{$\begin{array}{l}\mathrm{N} \\
\mathrm{O}\end{array}$} & \multirow{2}{*}{$\begin{array}{c}\text { Indicator } \\
\text { kompete } \\
\text { nsi } \\
\text { social }\end{array}$} & \multirow{2}{*}{$\begin{array}{c}\text { Sub } \\
\text { indicator } \\
\text { kompetensi } \\
\text { social }\end{array}$} & \multicolumn{8}{|c|}{ Nilai } & \multirow[t]{2}{*}{$\mathrm{Jml}$} & \multirow[t]{2}{*}{$\%$} \\
\hline & & & 4 & $\%$ & 3 & $\%$ & 2 & $\%$ & 1 & $\%$ & & \\
\hline \multirow[t]{3}{*}{1} & \multirow{3}{*}{$\begin{array}{c}\text { Living } \\
\text { and } \\
\text { Working } \\
\text { Togethe } \\
r\end{array}$} & Bergiliran & $\begin{array}{l}3 \\
5 \\
\end{array}$ & $\begin{array}{c}10 \\
0 \\
\end{array}$ & - & - & - & - & - & - & 35 & 100 \\
\hline & & $\begin{array}{c}\text { Menghormat } \\
\mathrm{i}\end{array}$ & 7 & 20 & 28 & 80 & - & - & - & - & 35 & 100 \\
\hline & & $\begin{array}{c}\text { Membantu/ } \\
\text { menolong }\end{array}$ & $\begin{array}{l}3 \\
5 \\
\end{array}$ & $\begin{array}{c}10 \\
0\end{array}$ & - & - & - & - & - & - & 35 & 100 \\
\hline \multirow[t]{2}{*}{2} & \multirow{2}{*}{$\begin{array}{l}\text { Learning } \\
\text { sel } \\
\text { control } \\
\text { and self } \\
\text { direction }\end{array}$} & $\begin{array}{l}\text { Mengikuti } \\
\text { petunjuk/atu } \\
\text { ran }\end{array}$ & $\begin{array}{l}3 \\
5\end{array}$ & $\begin{array}{c}10 \\
0\end{array}$ & - & - & - & - & - & - & 35 & 100 \\
\hline & & $\begin{array}{c}\text { Mengontrol } \\
\text { emosi }\end{array}$ & 4 & $\begin{array}{l}11 . \\
43 \\
\end{array}$ & 5 & 14.28 & 24 & 68.57 & 2 & 5.71 & 35 & 100 \\
\hline \multirow[t]{2}{*}{3} & \multirow{2}{*}{$\begin{array}{l}\text { Sharing } \\
\text { ideas } \\
\text { and } \\
\text { Experien } \\
\text { ces }\end{array}$} & $\begin{array}{l}\text { Menyampaik } \\
\text { an pendapat }\end{array}$ & 2 & $\begin{array}{c}5.7 \\
1\end{array}$ & 28 & 80 & 5 & 14.28 & - & - & 35 & 100 \\
\hline & & $\begin{array}{l}\text { Menerima } \\
\text { pendapat }\end{array}$ & 8 & $\begin{array}{l}22 . \\
85\end{array}$ & 20 & 57.14 & 7 & 20 & - & - & 35 & 100 \\
\hline
\end{tabular}


Berdasarkan data hasil post test antara metode Investigasi Kelompok dengan metode Number Heads Together (NHT) dapat diketahui bahwa skor post test terendah pada kelas metode Investigasi Kelompok 70 , sebanyak 2,85 siswa, skor post test terendah pada kelas eksperimen metode Number Heads Together (NHT) yaitu 63 , sebanyak $5,71 \%$ dari jumlah seluruh siswa. Skor nilai tertinggi pada kelas eksperimen pertama metode Investigasi Kelompok adalah 88, sebanyak $2,85 \%$ siswa, skor nilai post test terbanyak pada kelas eksperimen pertama metode Investigasi Kelompok berada pada nilai 74 sebanyak $14,28 \%$ siswa, frekuensi skor post test terbanyak pada kelas eksperimen kedua metode Number heads Together (NHT) berada pada nilai 74 sebanyak $17,14 \%$ siswa. Dengan demikian terdaapt perbedaan data post test pada kelas eksperimen pertama metode Investigasi Kelompok dan metode Number Heads Together (NHT).

Berdasarkan hasil perhitungan, skor nilai rata-rata post test pada kelas eksperimen pertama metode Investigasi Kelompok adalah 78,23, skor rata-rata nilai post test pada kelas eksperimen kedua metode Number Heads Together (NHT) adalah 73,06. Jika dibandingkan kedua skor rata-rata ini, ternyata skor rata-rata nilai post test kelas eksperimen pertama metode Investigasi Kelompok lebih tinggi daripada kelas eksperimen kedua metode Number Heads Together (NHT) dengan selisih skor 5,17.

Berdasarkan hasil penelitian dan analisis, dan setelah dilakukan observasi pada kegiatan pembelajaran, dimana kelas eksperimen pertama yang menggunakan metode Investigasi Kelompok dan kelas eksperimen kedua yang menggunakan metode Number heads Together. Masingmasing kelas eksperimen pertama dan kedua mempunyai nilai rata-rata post test kompetensi social yang berbeda dan hasil observasi yang berbeda pula.

Rata-rata post test kompetensi social kelas eksperimen pertama lebih tinggi dari pada kelas eksperimen kedua. Rata-rata skor kompetensi social kelas eksperimen pertama menggunakan metode Investigasi Kelompok (78.23) dan 
Didaktik : Jurnal IImiah PGSD STKIP Subang, ISSN Cetak : 2477-5673 ISSN Online : 2614-722X Volume V Nomor 2, Desember 2019

kelompok eksperimen kedua yang menggunakan metode Number Heads Together (73.06). nilai hasil observasi kompetensi social antara keduanya pun cukup jauh berbeda, penerapan metode Investigasi Kelompok pada perlakuan terakhir didominasi oleh 4 (sangat baik) pada mayoritas siswa.

Diperkuat dengan pendapat Slavin (2005:215) menyatakan bahwa: Pihak yang belajar adalah partisipan aktif dalam segala aspek kehidupan sekolah, membuat keputusan yang menentukan tujuan terhadap apa yang mereka kerjakan. Kelompok dijadikan sebagai sarana social dalam proses ini. Rencana kelompok adalah satu metode untuk mendorong keterlibatan maksimal para siswa.

Ditambah pula oleh Slavin (2005:16) sebagai berikut: Sebagai bagian dari investigasi, para siswa mencari informasi dari berbagai sumber baik di dalam maupun di luar kelas. Sumber-sumber seperti (bermacam buku, institusi, orang) menawarkan sederet gagasan, opini, data, solusi, atau posisi yang berkaitan dengan masalah yang dipelajari.
Sedangkan nilai observasi kompetensi social pada metode Number Heads Together (NHT) pada perlakuan terakhir cukup bervariasi, nilai 4 (sangat baik) terdapat pada subindikator bergiliran, membantu/menolong, dan mengikuti petunjuk/aturan, nilai 3 (baik) pada subindikator

menghormati, menyampaikan pendapat dan menerima pendapat. Sedangkan subindikator yang bernilai 2 (cukup baik) pada mengontrol emosi.

Melihat dari perbedaan skor post test kompetensi social dan nilai hasil observasi pada 2 kelompok, menunjukan bahwa metode pembelajaran investigasi kelompok dapat memberikan pengaruh yang signifikan terhadap kompetensi social siswa. Namun untuk menjawab hipotesis yang diajukan membutuhkan uji hipotesis dengan statistic.

Bila dihitung melalui uji Univariate Analysis of Variance (ANOVA) atau sering disebut dengan one-Way-ANOVA dan pada hasil test of between-subject effect bagian between group effect (pengaruh karena eksperimen) menggambarkan pengaruh keseluruhan dari eksperimen. Pada souce tipe Pemb 
Didaktik : Jurnal IImiah PGSD STKIP Subang, ISSN Cetak : 2477-5673 ISSN Online : 2614-722X Volume V Nomor 2, Desember 2019

(metode Pembelajaran), sum of squares dari model sebesar (SSm=1471.257) sedangkan maen square sebesar 735.629. sum of squares dari model sebesar menggambarkan rata-rata pengaruh eksperimen.

Adanya perbedaan rata-rata skor post test kompetensi social antara metode Investigasi Kelompok dan metode Number Heads Together dengan perbedaan nilai rata-rata antara keduanya sebesar 5.17 dengan signifikansi 0.00 . keadaan ini menunjukan bahwa metode Investigasi Kelompok memberikan peningkatan yang lebih besar terhadap kompetensi social siswa dibandingkan dengan Number Heads Together.

\section{Kesimpulan}

Kesimpulan yang dapat diambil yaitu terjadi perbedaan skor post test antara metode Investigasi Kelompok dengan metode Number Heads Together (NHT) terhadap peningkatan kompetensi social siswa. Setelah dilakukan perhitungan dengan menggunakan Univariate Analysis of Variance (ANOVA) hal ini menunjukan pembelajaran yang menggunakan metode Investigasi Kelompok lebih besar skor post test jika

dibandingkan

dengan pembelajaran yang menggunakan metode Number Heads Together (NHT). Berdasarkan hasil pengujian hipotesis didapat bahwa $\mathrm{H}_{\circ}$ ditolak. Berdasarkan hal tersebut terdapat peningkatan post test kompetensi social siswa pada kelas eksperimen pertama yang menggunakan metode Investigasi Kelompok dengan kelas eksperimen kedua yang menggunakan metode Number Heads Together (NHT).

Pennerapan metode Investigasi kelompok lebih baik dibandingkan dengan metode Number Heads Together (NHT) terhadap peningkatan kompetensi social siswa. Berdasarkan hasil penelitian 3 kali tindakan menunjukan hasil bahwa kelas eksperimen pertama yang menggunakan metode Investigasi Kelompok lebih baik dibandingkan dengan kelas eksperimen kedua yang menggunakan metode Number Heads Together (NHT).

\section{DAFTAR PUSTAKA}

Ali, M. (1993). Strategi Penelitian Pendidikan. Bandung: Angkasa

Al-Muchtar. (2004). Suwarma. Strategi Pembelajaran IPS. Bandung: Sps UPI.

Departemen Pendidikan Nasional. Standar Kompetensi dan 
Didaktik : Jurnal Ilmiah PGSD STKIP Subang, ISSN Cetak : 2477-5673 ISSN Online : 2614-722X

Volume V Nomor 2, Desember 2019

Kompetensi Dasar Tingkat SMP, MTS, SMPLB. Jakarta: Sekertariat Jendral Departemen Pendidikan Nasional Republik Indonesia, 2006.

Ibrahim, M. (2000). Pembelajaran Kooperatif. Surabaya: Universitas Negeri Surabaya. University Press.

Iskandar, M. (2000). Metode Penelitian Pendidikan dan Sosial (Kuantitatif dan Kualitatif). Jakarta: Gaung Persada Press.

Majid, A. (2013). Strategi Pembelajaran. Bandung: Remaja Rosdakarya.

Maryani, E. (2011). Pengembangan Program Pembelajaran IPS untuk Meningkatkan Keterampilan Sosial. Bandung: Alfa Beta.

Mc. Millan and Sally S. (1989). Research in Education a Conceptual Indtroduction Second Edition. USA: Harper Collins Publisher.

Mulyasa, E. (2009). Kurikulum Tingkat Satuan Pendidikan. Bandung: Remaja Rosdakarya.

Sapriya. (2009). Pendidikan IPS Konsep dan Pembelajaran. Bandung: Remaja Rosdakarya.

Santoso, Singgih. (2001). SPSS, mengolah Data Statistik Secara Profesional Versi 17.5. Jakarta: PT Elex Media Koputindo.

Slavin, R.E (2005). Cooperative Learning Teori, Riset dan Praktik. Bandung: Nusa Media.

Somantri, Numan Muhamad. (2001). Menggagas Pembaharuan Pendidikan IPS. Bandung : Remaja Rosdakarya.
Sugiyono. (2009). Metode Penelitian Pendidikan. Bandung: Alfabeta.

Sumaartmadja, N. (1998). Metodologi Pengajaran Geografi. Jakarta: Bumi Aksara.

Syaodih, Nana. (2004). Kurikulum dan Pembelajaran kompetensi. Bandung: Yayasan Kesuma karya.

Trianto. (2007). Model-model Pembelajaran Inovatif Beroreientasi Konstruktivistik. Surabaya: prestasi Pusaka.

Usman, M.U. (2009). Menjadi Guru Profesional. Bandung: Remaja Rosdakarya

Wahab, A. (2007). Metode dan Model-Model mengajar IPS. Bandung: Alfabeta.

Wiriatmadja, Rochiati. (2008). Metode Penelitian Tindakan Kelas. Bandung: Remaja Rosdakarya. 